\title{
Toll-Like Receptor Family Gene
}

National Cancer Institute

\section{Source}

National Cancer Institute. Toll-Like Receptor Family Gene. NCI Thesaurus. Code C25965.

Expressed in a variety of tissues, Toll-Like Receptor Family Genes encode type I transmembrane Toll-Like Receptor proteins, containing a TIR domain and multiple LRR repeats, which respond to various microbial components and mediate pathogen recognition and activation of innate immunity to microbial agents. Sharing structural and functional similarities, hig hly conserved TLRs recognize pathogen-associated molecular patterns expressed on infectious agents and mediate cytokine production necessary for effective immunity. TLRs typically act via MyD88 (TIR interaction) and TRAF6, activating NF-Kappa-B, cytokine production and secretion, and inflammatory response. $(\mathrm{NCl})$ 